\title{
Design of a Hybrid System for Rural Area Electricity Supply in Comoros
}

\author{
Kassim Mohamed Aboudou, ${ }^{1,2}$, Mohamed El Ganaoui \\ ${ }^{1}$ Energy and Applied Mechanics Laboratory, LEMA, Physics and Mathematics Department, Faculty of Sciences and Techniques, \\ University of Comoros, Moroni, Comoros \\ ${ }^{2}$ Laboratory of Energetic, LERMAB, IUT Henri Poincaré, 186 route de Lorraine Cosnes-et-Romain, Longwy, University of \\ Lorraine, Nancy, France \\ Email: kassim2005k@gmail.com
}

How to cite this paper: Aboudou, K.M. and El Ganaoui, M. (2019) Design of a Hybrid System for Rural Area Electricity Supply in Comoros. Journal of Power and Energy Engineering, 7, 59-78. https://doi.org/10.4236/jpee.2019.72005

Received: October 3, 2017

Accepted: February 24, 2019

Published: February 27, 2019

Copyright (c) 2019 by author(s) and Scientific Research Publishing Inc. This work is licensed under the Creative Commons Attribution International License (CC BY 4.0).

http://creativecommons.org/licenses/by/4.0/

cc) (†) Open Access

\begin{abstract}
Comoros Islands suffering from energy stress due to rolling power cuts in the country mainly due to problems with failures heat engines fuelled with diesel. These blackouts induce shortages of energy while demand for energy does not cease to grow with the population. An alternative way for the Comoros Islands to get out of this energy crisis is to exploit the existing energy renewable sources, in particular to invest in the hybrid energy, a promising technology in terms of economic efficiency. The north of Ngazidja Island, in the region of Mitsamiouli, is considered among the economic lungs of this Island. It is spread in the field of tourism but also an area developed in agriculture and fishing. The Village of Koua Mitsamiouli located in rural area of this region is well known for its efficient yield in agricultural production, although the latter suffers from an energy stress in its last years. This lack of energy and water permanently to farmers has caused its production capacity to fall. In order to increase its agricultural profitability, and to satisfy the needs of the population for their activities such as trade, health, education, banking transactions, product preserving in retail stores, the energy autonomy of this village is more than necessary. It is important to notice that, the use of renewable energies in Comoros is very limited by photovoltaic (PV) solar panels. Hybrid technology and other renewable energy sources are not yet developed in Comoros Island. The main objective of this work is to propose the best possible sizing of a hybrid system for the production of electricity from renewable and non-renewable energy resources in order to satisfy the electrical needs in a reliable manner of the remote of village, Koua Mitsamiouli, for energetic autonomy. Indeed, two energy resources, composed by solar photovoltaic (PV) system and diesel generator are considered in the hybrid system. This study estimates the community demand with HOMER analysis. In
\end{abstract}


order to check the performance of the overall system combination photovoltaic $(\mathrm{PV}) /$ generator, several numerical simulations were performed with the HOMER software using data from the national meteorological agency in Comoros and the results obtained by authors are satisfactory in terms of cost and reliability of the system.

\section{Keywords}

Photovoltaic (PV) Array, Diesel Generator, Hybrid System, Rural Area, Energy Autonomy

\section{Introduction}

Comoros is a sovereign African state on the west three-quarters of the Comoros archipelago, located in the Indian Ocean north of Madagascar in $12^{\circ} 08^{\prime}$ South and $44^{\circ} 15^{\prime}$ Est, which has a territorial claim on the remaining quarter. This archipelago is located at the northern end of the Mozambique Channel, between Mozambique and the island of Madagascar. The islands are known by their French names, but they are appointed by the Comoros Comorian government with their names Ngazidja (Grande Comoros), Mwali (Moheli), Ndzuwani (Anjouan) and Maoré (Mayotte) under the French administration. The four Comoros islands have an area of $2236 \mathrm{~km}^{2}$. Ngazidja island is the most northwest of the archipelago; it is distant 40 miles from Mwali, 80 kilometers Ndzuwani and 200 kilometers of Mayotte (101st department of the French Republic). Ngazidja or Grande Comoros is the largest island, measuring $77 \mathrm{~km}$ long and $27 \mathrm{~km}$ wide with an area of $1146 \mathrm{~km}^{2}$. It is the youngest island of the archipelago. Two volcanoes form the topography of the island. To the north there is the grille with an altitude $1087 \mathrm{~m}$ and Karthala in the south $(2361 \mathrm{~m})$, which last erupted in 1977. Comoros population is 806,153 inhabitants (2016). The capital of the Comoros is Moroni with a population of 111,329 inhabitants (in 2016 census). Our study was conducted in northern of Ngazidja at Koua Mitsamiouli area in the Mayor of Sada Djoulamlima. Koua is a small village of 850 inhabitants located in Northern of Ngazidja in the $-11^{\circ} 40^{\prime}$ South latitude and $43^{\circ} 33^{\prime}$ EST Longitude on which has enormous potentials in agriculture but suffers with the stress energy caused by recurrent problem of lack of electricity in Comoros. The estimate land elevation above sea level is 80 meters. Taking account of this situation, the farmers and the villagers are unable to properly operate to meet population needs for food products without permissiveness of energy. We propose in the present study, the design of a PV/generator hybrid system for power supply requirements. Indeed, in the literature [1]-[12], the hybrid renewable energy system is defined as any energy production system with more than one conventional diesel-fueled generator and a renewable energy source such as PV, wind or The $\mathrm{PV} /$ wind combination. Researchers have shown that, over the next 40 years, oil reserves will be depleted due to rapid population growth, the need for massive 
energy consumption, rising oil prices, environmental pollution, the problem of global warming, the shortage of electrical energy that invades the world, impose the use of renewable energy resources. To do this, photovoltaic energy is preferable because it is non-polluting, site-dependent and a potential source of alternative energy options. The HOMER version 2.68 software developed by the National Renewable Energy Laboratory (NREL) was used as a sizing and optimization tool. Indeed, we find in this software a model of energy components. It also proposes and evaluates options and technological parameters in line with costs and also with the availability of resources. The use of the HOMER software as a sizing tool requires several information about renewable energy resources, the economic constraints linked to the project and also the methods of control. It asks for inputs such as the type of component, their numbers, cost, efficiency, lifetime ... etc. On the other hand, the sensitivity analysis could be done with parameters for a margin of values instead of a specific number. Several research studies have been carried out using a calculation method for the size of the components of the hybrid system and the optimization of costs according to the need for the load and the energy resources available on the sites. Indeed, Abdullah and Hadj Bourdoucen [13] carried out an economic analysis of the hybrid system for rural electrification in Oman. Their work involves a feasibility study on the integration of a wind turbine into an existing diesel plant in the remote Duqum region of the Sultanate of Oman. The simulation model used by the authors takes into account the wind data of the Al Duqm meteorological station as well as the actual loading data of Duqum. The authors used HOMER to carry out their study for the hybrid system without battery storage. The authors showed that for the wind speed less than $5 \mathrm{~m} / \mathrm{s}$, the diesel power station seems to be the best suitable solution according to the range of fuel prices used in the numerical simulation. Their results show that for wind speeds up to $6 \mathrm{~m} / \mathrm{s}$ the proposed hybrid system becomes feasible with a fuel cost of 0.368 US $\$ / L$ or more, the current diesel cost in Duqm. On the other hand, Elhadidy [14] on his side has shown in the same sense that the autonomous wind energy system does not produce usable energy during a considerable part of the time during the year for a wind speed relatively high, in the range of 3.5 to $4.5 \mathrm{~m} / \mathrm{s}$. An approach of a hybrid multi-source system for optimal operational control in order to meet the load energy requirement with reliability and minimized life-cycle costs was carried out by Kanzumba and Herman [15]. The authors limited their results on both the formulation of the problem and the development of the mathematical model in order to obtain the performance of all components of the hybrid system. Their results show that the variables of the developed model can be optimized in order to minimize life cycle costs while satisfying demand. A simulation study and optimization of autonomous hybrid systems of renewable energy was carried out by José and Rodolfo [16]. Their study focuses on the revision of simulation and optimization techniques, as well as the existing tools needed to simulate and design a stand-alone hybrid system for power generation. Their results show that the most frequently used systems are those composed of a 
combination of photovoltaic generator and/or wind turbines and/or a diesel generator, with energy storage in lead-acid batteries. It is important to note that the authors state that stand-alone hybrid power generation systems are generally more appropriate than systems that have only one power source for supplying power to off-grid applications, remote or rural areas where access seems difficult. Recently, a feasibility analysis of PV/Wind/Battery hybrid power generation has been investigate be [17] using HOMER software as tool for technical and economic in order to supply electric energy for remote rustic school in the southern part of Iraq. Authors are explained in details the analysis of the optimal energy systems in order to find the most feasibility off-grid system. Author analysis shows that hybrid energy system which consist of $5 \mathrm{~kW} \mathrm{PV}, 1$ wind turbine, 19 units of battery and $4 \mathrm{~kW}$ converter is the most optimum hybrid system.

The main objective of this work is to analyze the economic feasibility of a diesel power plant to produce energy in a remote area with the combination of solar photovoltaic panels in the system to reduce fuel consumption as well as environmental pollution. The focus was on saving and reducing the percentage of fuel carbon emissions for reduction in greenhouse gas emissions to fight against climate change but also reduce electricity cost system.

\section{The Components of Hybrid Energy System}

A hybrid system is generally composed of a primary renewable energy source that combines in parallel with a pending non-renewable storage module and unit. In fact, Figure 1 describes a general scheme of an autonomous power generation system. On the other hand, we have shown in Figure 2 the equivalent circuit diagram of the hybrid system, while in Figure 3 we show the schema established by the MOHER software tool. Our proposed hybrid system consists of a diesel generator; a photovoltaic network system used to charge a battery tank, a battery storage system, an inverter that converts the DC power stored in the battery tank into alternating current $(\mathrm{AC})$ to a standard voltage level and frequency, and then supply it to the load. A configuration with a parallel hybrid system composed by (Figure 3), a diesel generator and a supply of renewable energy system of the load demand directly are presented. The parallel hybrid feed system, as shown in Figure 3, is a DC coupling configuration where the renewable energy generators are connected to a battery through the DC bus and power the AC load through the bi-directional inverter. The functional schemes of the system's different components in terms of energy are presented below [18]:

\subsection{System Modeling}

The rural village where this study was conducted is Koua Mitsamiouli, a small area located in the Northern of Ngazidja in the $-11^{\circ} 40^{\prime}$ South latitude and $43^{\circ} 33^{\prime}$ Est Longitude, an area in the Mayor of Sada Djoulamlima. Villagers consume water tanks and have no permanent access of electrical energy caused by le problem of electricity in the national society producer of energy said 
(MAMWE). Indeed, in remote rural village, the electricity demand use is not the same as in urban areas. Electricity in rural village is demanded for domestic activities as (refrigerator, radio, television, computer, charging phone, lamps, etc.), community activities (marriage, agriculture activities, schools, mosques and clinics). It's used again for rural commercial and small-scale industrial activities (such as fish and meat cold storage, food products and cottage industries).

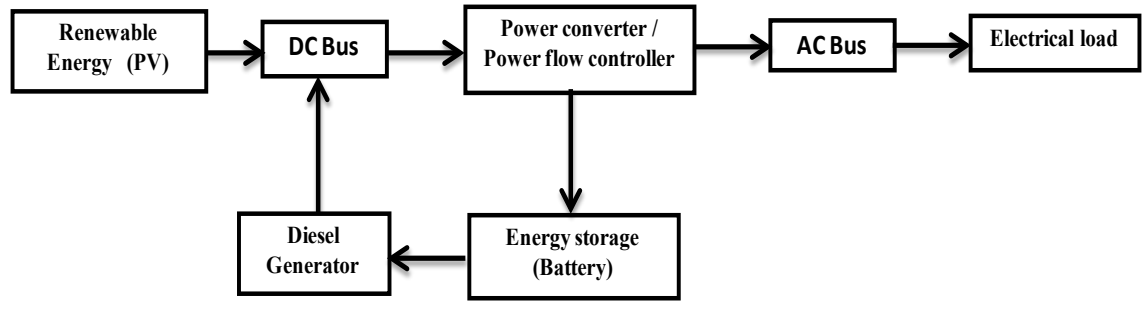

Figure 1. Scheme descriptive of hybrid power system.

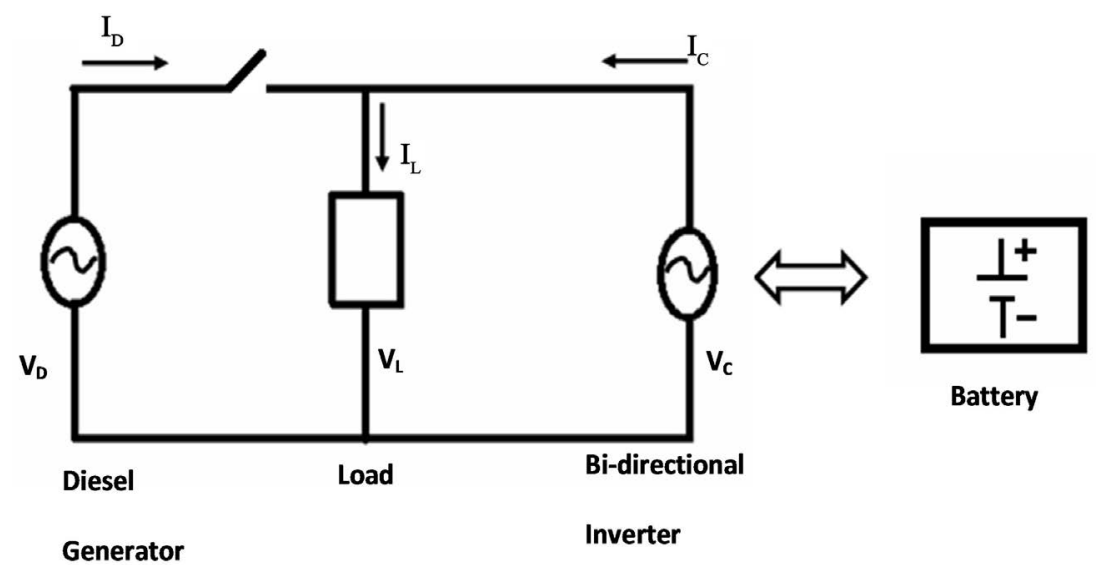

Figure 2. Equivalent circuit diagram of hybrid system.

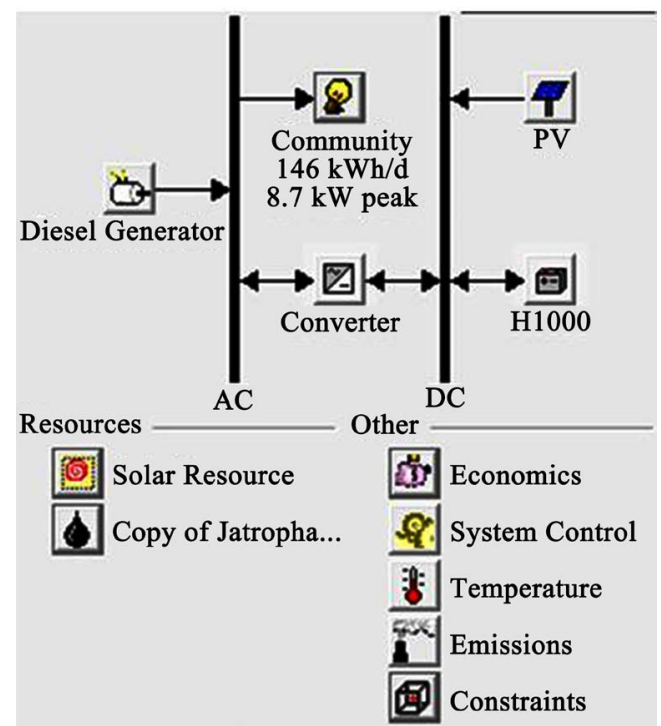

Figure 3. HOMER implementation of the hybrid energy system. 


\subsection{Description of Diesel Generator}

The Diesel Generator (DG) is known as a diesel engine coupled to a generator. This DG can generate at nominal power. Thus the excess energy observed can be used to charge a battery in general. Indeed, DG is designed in such a way that it runs between $75 \%$ and $100 \%$ of the evaluation in $\mathrm{kW}$ running with battery or other renewable energy systems. The electrical power supply in the Village of Koua Mitsamiouli is achieved by using diesel generator of $120 \mathrm{~kW}$. This is included I the simulation in order to make comparison of the system with other feasibility systems. Generated DG (EDG) with nominal power (PDG) is given by [15]:

$$
E_{D G}=P_{D G} * \eta_{D G} * t
$$

For the present study, the costs of capital for diesel generator are such that $\$ 600 / \mathrm{kW}$. Replacement and operation costs are assumed to be $\$ 550 / \mathrm{kW}$ and $(\$ 0.05 / \mathrm{hr} / \mathrm{kW})$ respectively.

\subsection{Renewable Resources}

The solar energy resource is considered in this work. We conducted a sensitivity analysis for suitable results in other areas of the Village.

\section{Solar Energy}

The average daily sunshine Northern Ngazidja is 10 hours time per day with an average power of $5.29 \mathrm{~kW} / \mathrm{m}^{2} / \mathrm{d}$ of production. Ngazidja meteorological data between 1961 and 2016 shows an effective sunshine whatever the month or season [19]. The Comoros also receives a very important solar radiation rate. These values show that the country has a high level of solar radiation capable of supplying photovoltaic and solar thermal installations. Indeed, HOMER retrieves the clearness index via the information present on the latitude of the site under investigation (Figure 4).

\section{Photovoltaic Array}

Technical parameters and costs of Photovoltaic are resented in Table 1.

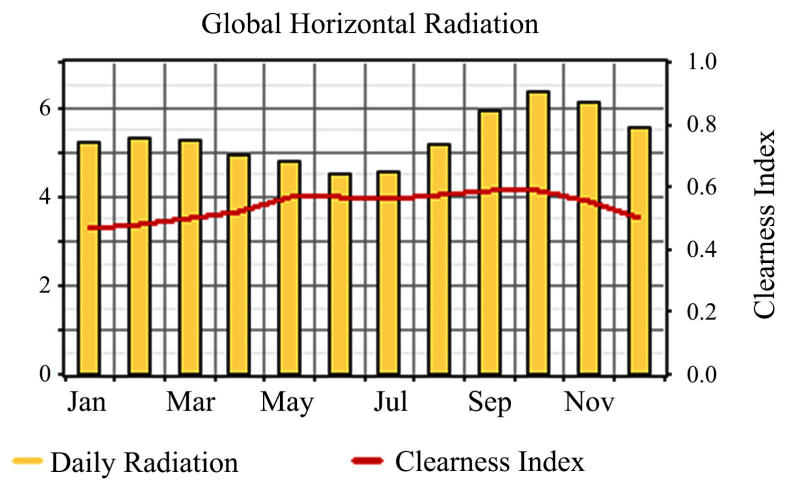

Figure 4. Average daily radiations of earth. 
Table 1. Technical parameters and costs of PV.

\begin{tabular}{cc}
\hline Parameters/Costs & Value \\
\hline Derating factor & $80 \%$ \\
Nominal operating cell temperature & $47^{\circ} \mathrm{C}$ \\
Temperature coefficient of power & $-0.5 \% /{ }^{\circ} \mathrm{C}$ \\
Efficiency at standard test condition & $13 \%$ \\
Ground reflectance & $20 \%$ \\
Capital cost & $\$ 5000 / \mathrm{kW}$ \\
Replacement cost & $\$ 4500 / \mathrm{kW}$ \\
Operating and maintenance cost & $\$ 1 / \mathrm{kW} / \mathrm{yr}$ \\
Lifetime & 25 years \\
Tracking system & No tracking
\end{tabular}

\subsection{Incident Radiation on the PV Array}

The solar inclination is calculated from the following equation given below

$$
\mathrm{w}: \delta=23.45^{\circ} \sin \left(360^{\circ} \frac{284+n}{365}\right)
$$

where $n$ is the day of the year [a number 1 through 365]. In the other hand, an hour angle is given as the time of day affects the location of the sun sky. It can be calculated from the following equation:

$$
\omega=\left(t_{s}-12 \mathrm{hr}\right) 15^{\circ} / \mathrm{hr}
$$

where $t_{s}$ is the solar time. It is important to notice that $t_{s}$ is $12 \mathrm{hr}$ at solar noon, and $13.5 \mathrm{hr}$ ninety minutes later. Equation (3) shows that that the sun moves across the sky at 15 degrees per hour. HOMER performs the calculations assuming that all time-dependent data such as solar radiation and electric charge are not given in solar times, but rather in civil time also known as local standard time calculated from the equation below:

$$
t_{s}=t_{c i}+\frac{\lambda}{15^{\circ} / \mathrm{hr}}-Z_{c}+E
$$

where $t_{c i}$ is the civilian time in hours and $\lambda$ is the longitude, $Z_{c}$ is the time zone corresponding to the hours east of GMT and $\mathrm{E}$ is the hourly equation. This template was designed for two affiliations.

\subsection{The Photovoltaic Cell Temperature}

We have to notice that the temperature of the photovoltaic cell is defined as being the temperature of the surface of the photovoltaic array. The energy balance for the PV array is given by [20]:

$$
\tau \alpha G_{T}=\eta_{c} G_{T}+U_{L}\left(T_{c}-T_{a}\right)
$$




\section{Battery}

Surrette S6CS25P battery is used in this present work and technical parameters and cost of battery are summarized in Table 2. On the other hand, the battery has capacity to store a particular quantity of DC electricity with constant energy efficiency round trip able to limit the charging or discharging time without causing any damage in the system.

The battery bank life is calculated by the following equations:

$$
\begin{gathered}
R_{\text {batt }}= \begin{cases}\frac{N_{\text {batt }} * Q_{\text {lifetime }}}{Q_{\text {thrpt }}} & \text { If limited by throughput } \\
R_{\text {batt }}=R_{\text {batt }}, f \quad \text { If limited by time }\end{cases} \\
R_{\text {batt }}=\left\{M I N\left(\frac{N_{\text {batt }} * Q_{\text {lifetime }}}{Q_{\text {thrpt }}} ; R_{\text {batt }, f}\right)\right.
\end{gathered}
$$

If limited by throughput and time

Rbatt is the battery life, Nbatt the number of batteries in the battery, Qlifetime the lifetime throughput of a single battery, Qthrpt the annual battery throughput and Rbatt, the battery float life. The evolution of discharge current of battery is presented in Figure 5.

Table 2. Technical parameters and costs of the battery (Surrette 6CS25P).

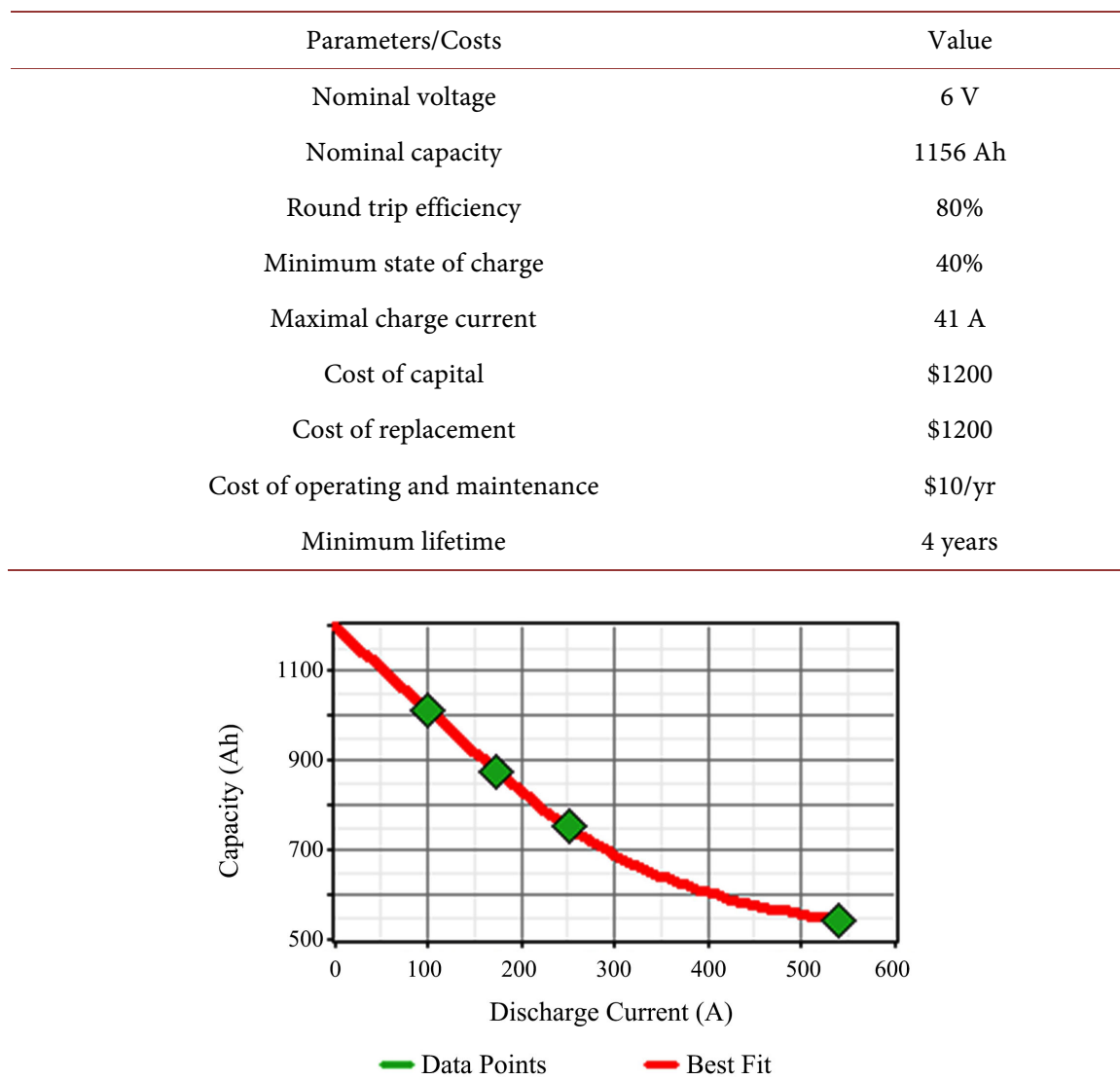

Figure 5. Evolution of discharge current of battery. 


\section{Power Converter}

In order to preserve the passage of energy between $\mathrm{AC}$ and direct power systems a converter is more than necessary. For this, the inverter output AC current must be similar to or greater than maximum load. The technical parameters and converter costs are summarized below in Table 3 .

\section{Economics and Constraints}

The project lifetime is 25 years with annual interest rate of $8 \%$. In our system, fixed capital cost is $2500 \$$. In the other hand, operations and maintenance costs for nominal annual value (90\$) is considered. Sensitivity parameters of maximum annual capacity shortage have been studied while the operating reserve, as percentage of hourly load is $10 \%$. For solar energy, renewable energy output is taken as $25 \%$.

\section{Temperature}

HOMER used ambient temperature data to calculate the power produced by the panels PV array in each time step. In fact more the temperature is elevated, more efficiency photovoltaic panels is low. We have use numerical data of average monthly temperature offer by the National Agency for Meteorology Comoros, Moroni (ANACM) see Figure 6.

Table 3. Technical parameters and costs of the converter.

\begin{tabular}{cc}
\hline Parameters/Costs & Value \\
Efficiency & $95 \%$ \\
Cost of capital & $\$ 600 / \mathrm{kW}$ \\
Cost of replacement & $\$ 550 / \mathrm{kW}$ \\
$\begin{array}{c}\text { Cost of operating } \\
\text { and maintenance }\end{array}$ & $\$ 5 / \mathrm{kW} / \mathrm{year}$ \\
Lifetime & 15 years \\
\hline
\end{tabular}

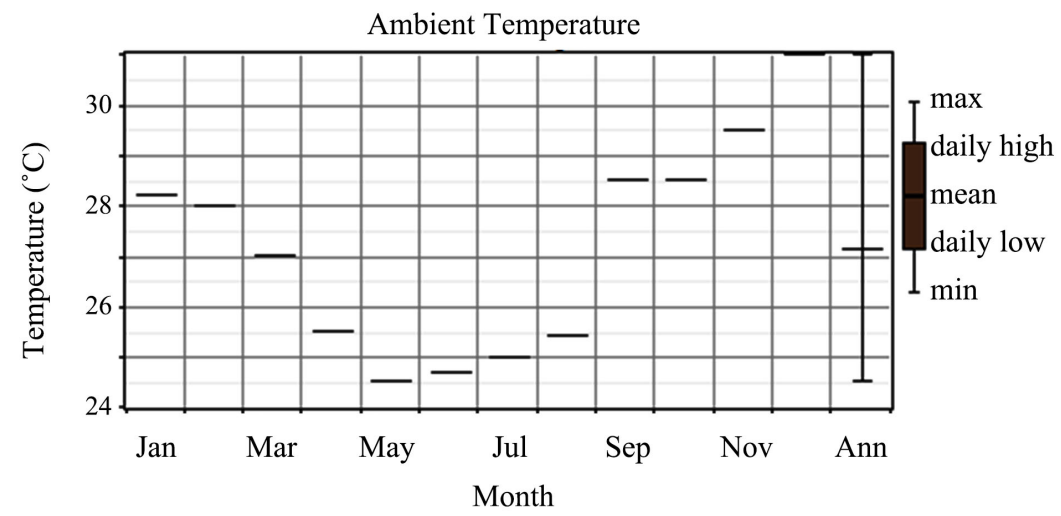

Figure 6. Average monthly temperatures. 


\section{Load Daily Profile}

The values of the hourly load for each month are presented in Figure 7(a) and Figure 7(b). Therefore, it is assumed that the demand for electricity does not vary according to the season because, in the Comoros, we have a tropical climate. The consumption of electricity remains for the moment a basic consumption of everyday life such as electrification of residence, TV, radio, DVD player, fridge ... etc. By analyzing this figure, we notice that the peak $8.7 \mathrm{~kW}$ is expressed between $18 \mathrm{~h}$ and $21 \mathrm{~h}$ where the demand for consumption is high in households.

\section{Results and Discussions}

\subsection{Sensitivity Results}

Three sensitive variables (solar radiation, Jatropha oil price and maximum annual capacity shortage) are considered in this present analysis. Indeed, the sensitivity values are simulated by HOMER for all systems as well as the simulations of temporary series for each type of system possible. Configuration is carried out for a period of 1 year.

HOMER software eliminates all impracticable systems and presents the results in terms of total net present cost (NPC) [21] [22] [23] [24] [25]. In this study, solar radiation average of $\left(5.29 \mathrm{kWh} / \mathrm{m}^{2} / \mathrm{d} ; 6.11 \mathrm{kWh} / \mathrm{m}^{2} / \mathrm{d}\right.$ and $\left.7.00 \mathrm{kWh} / \mathrm{m}^{2} / \mathrm{d}\right)$, Jatropha price of $(0.92 \$ / \mathrm{L} ; 1.00 \$ / \mathrm{L}$ and $1.25 \$ / \mathrm{L})$ and maximum annual shortage of $(3 \%, 5.2 \%$ and $5.4 \%)$ were used as a sensitivity variables. A total of 27 sensitivity cases were tried for each configuration. Overall 2700 systems were simulated for 27 sensitivity with a simulation times of $18 \mathrm{~h} 36 \mathrm{mn}$ in Lenovo INTEL Core i3 $4005 \mathrm{U}$ personal computer with $1.70 \mathrm{GHz}$. Optimization result hybrid system has been investigated in the present study. Results are presented in terms of global solar irradiation, Jatropha oil price and maximum annual capacity shortage in Figures 8-11. Various of optimal system type (OST) is display as function of the sensitivity parameters in these plots.

Figures 8(a)-(c) represents an optimal system type provides that a system will be optimal at certain global solar radiation and Jatropha oil price. Figure 8(a) presents the total net present cost (NPC) of the system considering a maximum annual capacity shortage (MACS) of $3 \%$. (NPC) varied from $348,789 \$$ and takes high value with increasing of Jatropha oil price as is explain in the plot for a Jatropha oil price less than $1.14 \$ / \mathrm{L}$. In this case Gens system is advantageous and (NPC) value varied from point to point depending on global solar radiation. Indeed, when Jatropha oil price is higher then $1.16 \$ / \mathrm{L}$ for PV/Gens/Battery system might be suitable.

In Figure $8(\mathrm{~b})$ (NPC) if we allow for $5.2 \%$ of maximum annual capacity shortage the hybrid system works with three categories of system. The first one Gens system is observed for a Jatropha oil price less than $1.15 \$$ / with a decreasing slope from $0.92 \$ / \mathrm{L}$ to $1.15 \$ / \mathrm{L}$ and a solar global radiation varying from 6.09 $\mathrm{kWh} / \mathrm{m}^{2} / \mathrm{d}$ to $6.92 \mathrm{kWh} / \mathrm{m}^{2} / \mathrm{d}$. In this case minimum and maximum value of 


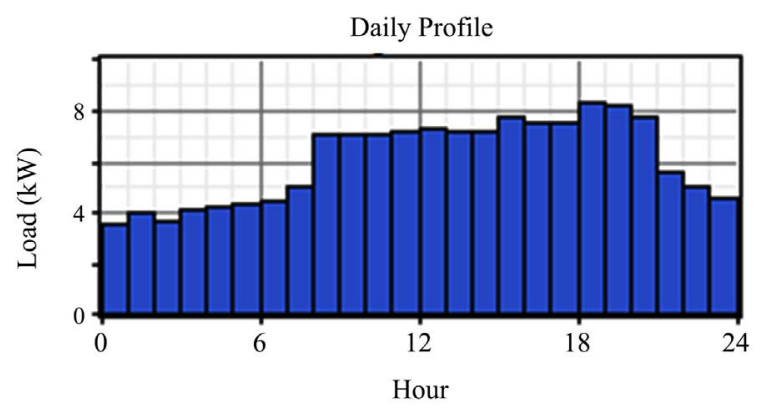

(a)

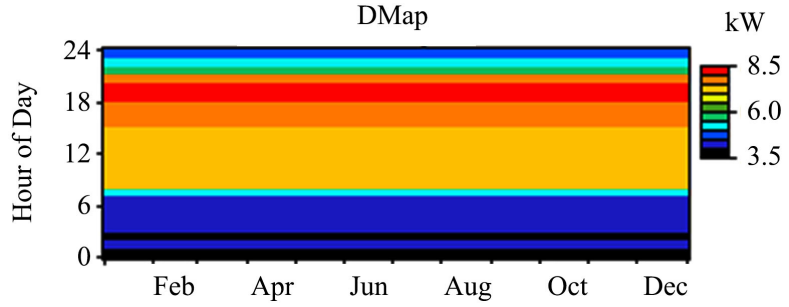

(b)

Figure 7. (a) Load daily profile; (b) Load daily profile.

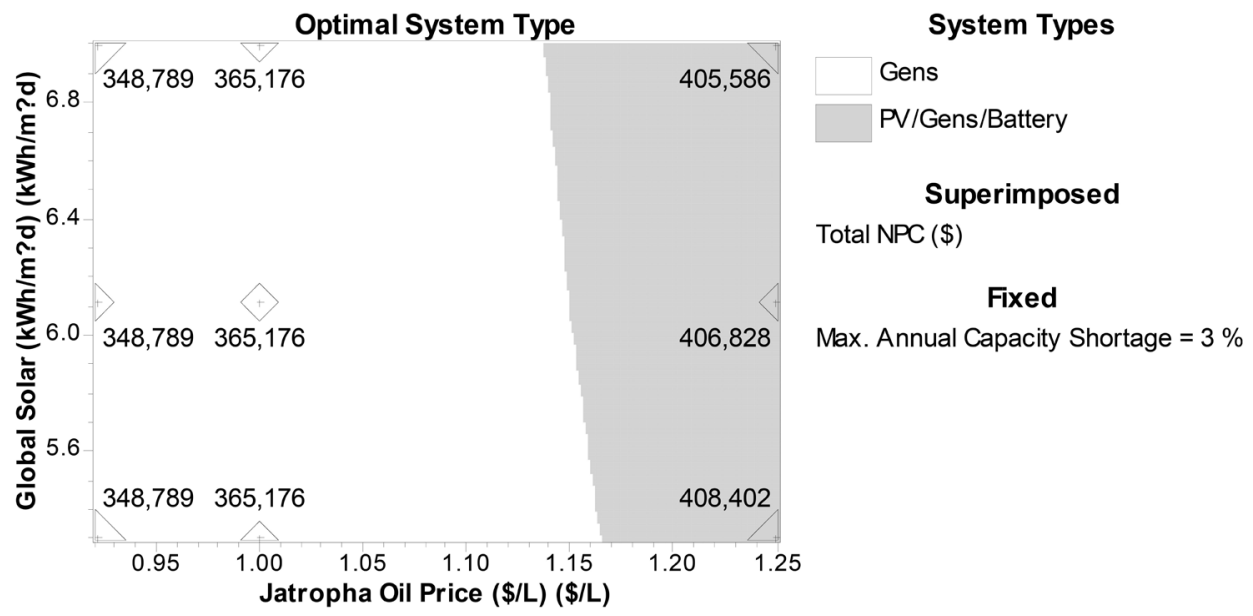

(a)

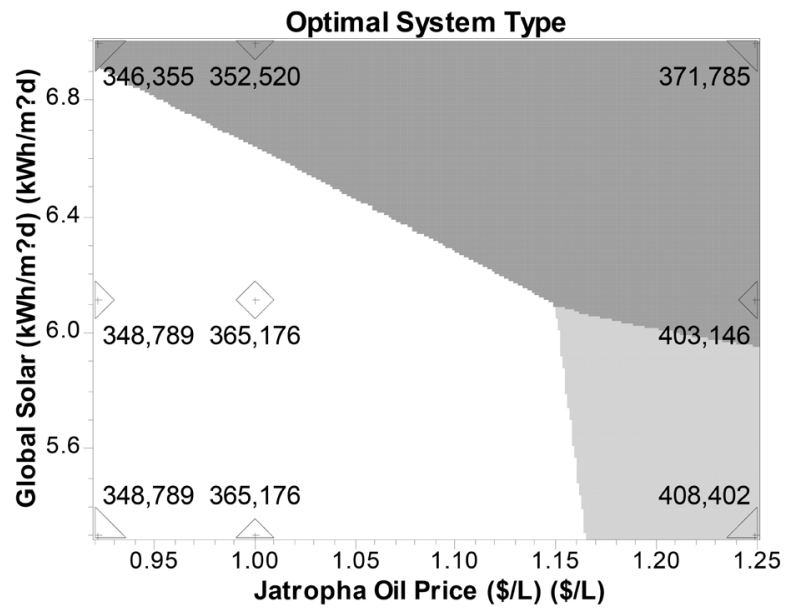

System Types

Gens

PV/Gens

PV/Gens/Battery

Superimposed

Total NPC (\$)

Fixed

Max. Annual Capacity Shortage $=5.2 \%$

(b) 


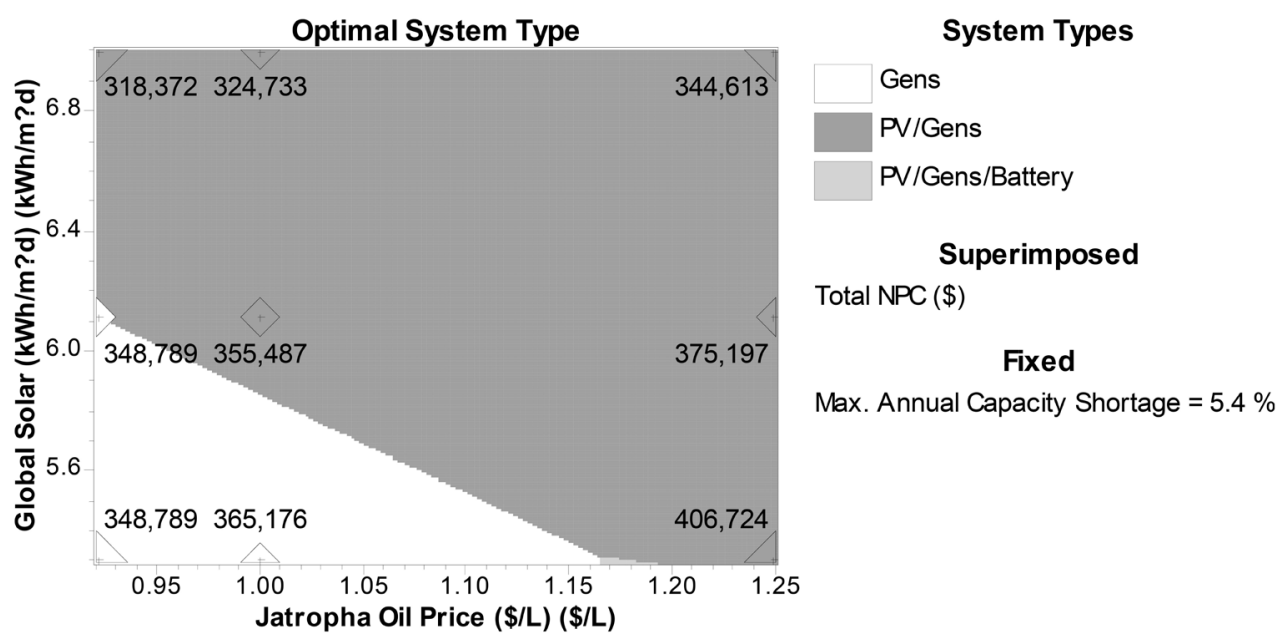

(c)

Figure 8. (a) OST Total Net Present Cost (NPC) for MACS = 3\%; (b) OST Total Net Present Cost $(\mathrm{NPC})$ for MACS $=5.2 \%$; (c) OST Total Net Preesnt Cost (NPC) for MACS $=5.4 \%$.

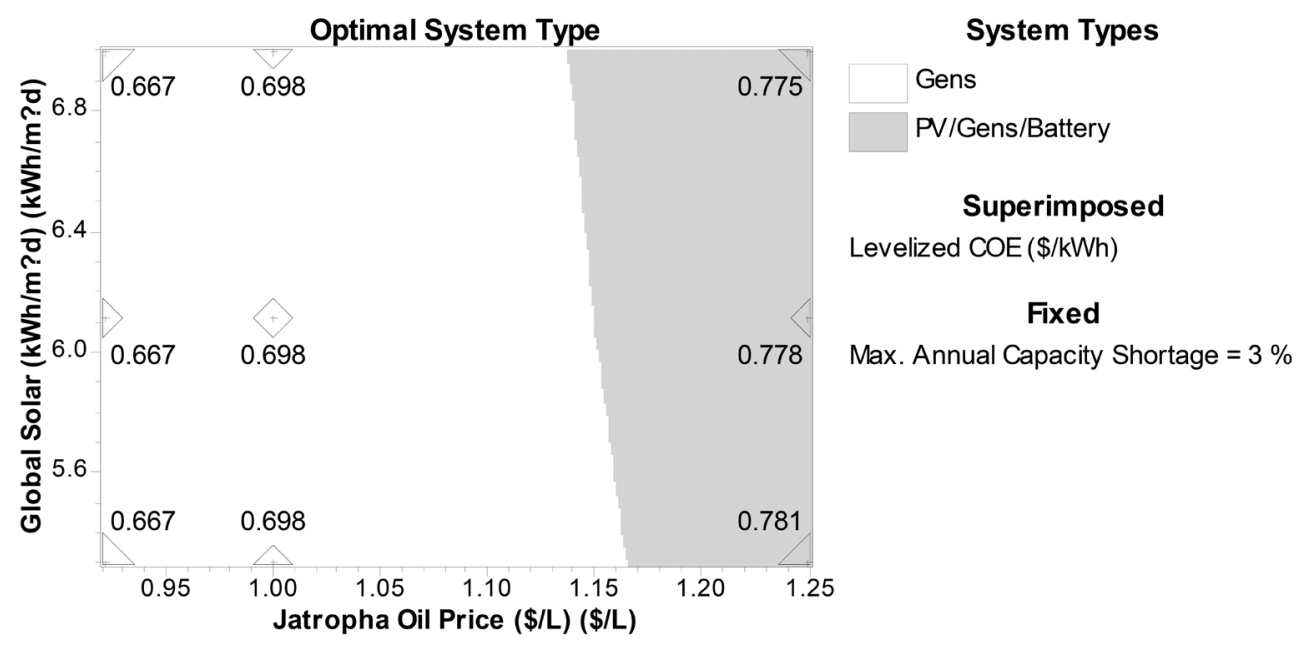

(a)

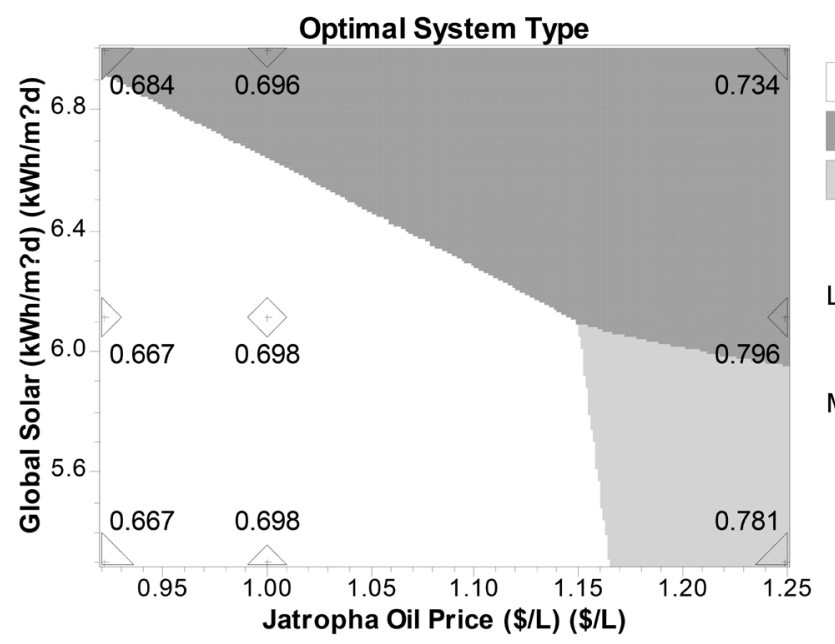

System Types

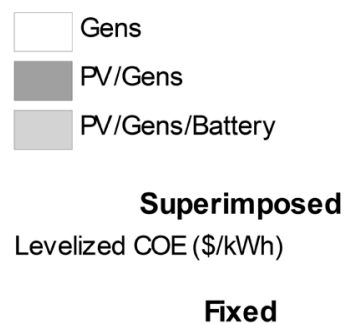

Max. Annual Capacity Shortage $=5.2 \%$

(b) 


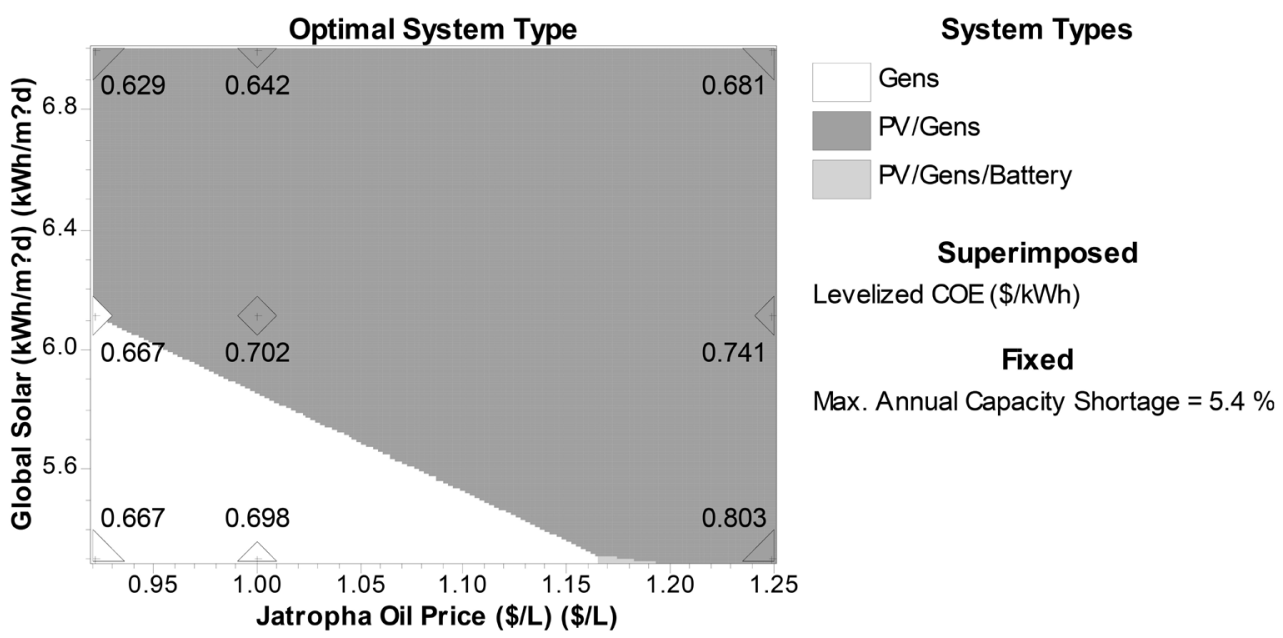

(c)

Figure 9. (a) OST Cost of Energy (COE for MACS = 3\%); (b) OST Cost of Energy (COE) for MACS $=5.2 \%$; (c) OST Cost of Energy $(\mathrm{COE})$ for MACS $=5.4 \%$.

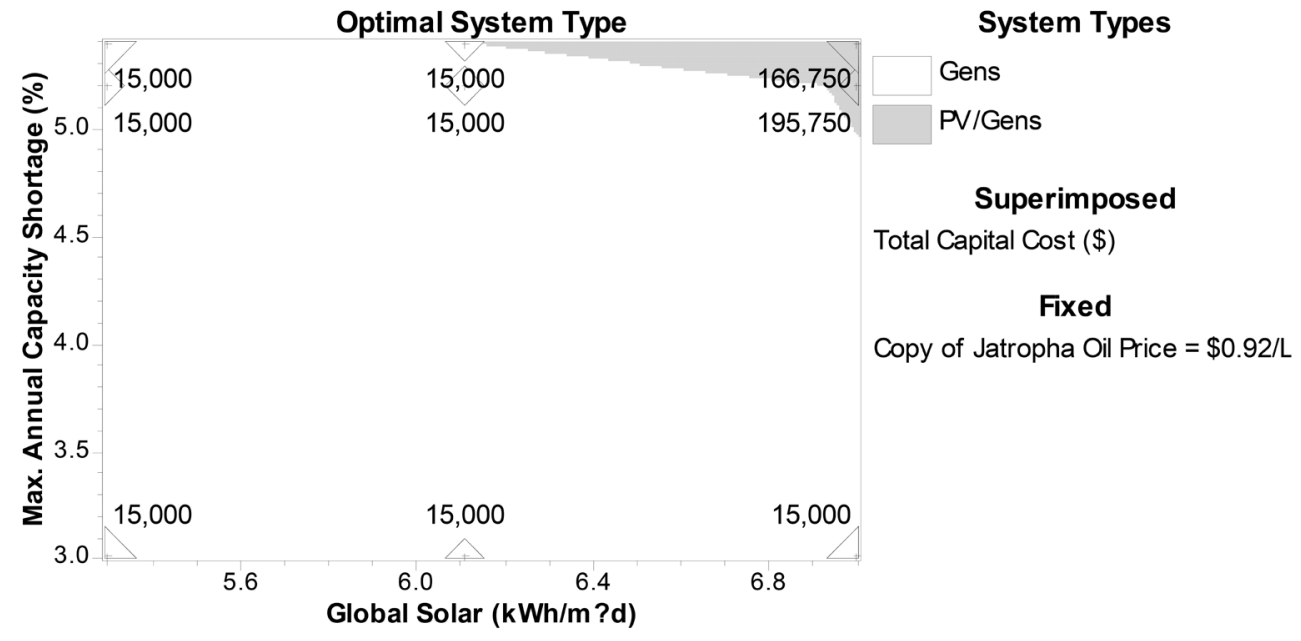

(a)

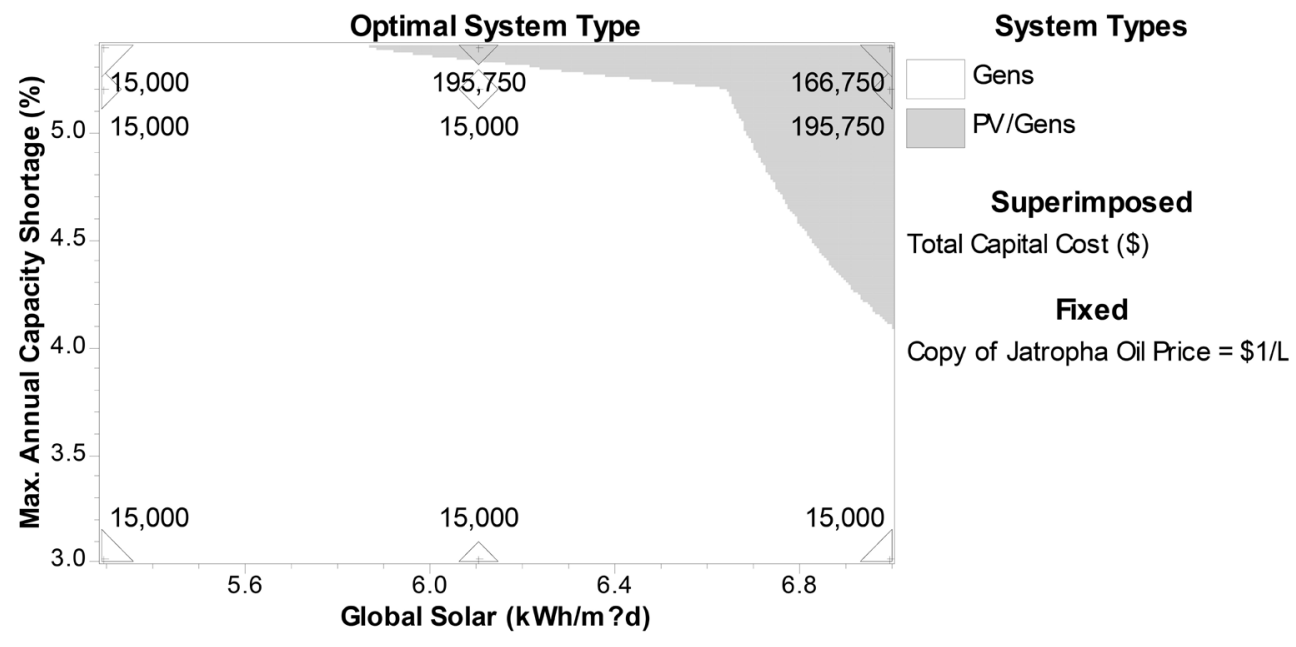

(b) 


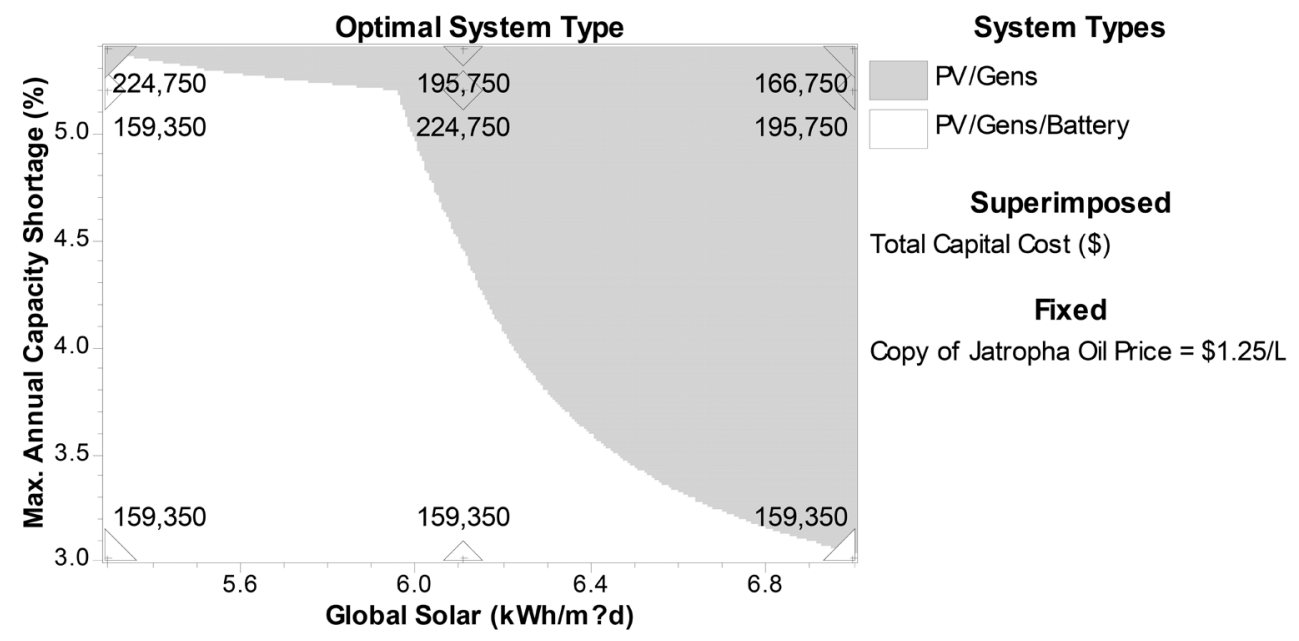

(c)

Figure 10. (a) OST of Total Capital Cost for Jatropha Oil Price of (OP) $=0.92 \$ / L$; (b) OST of Total Capital Cost for Jatropha Oil Price of $(\mathrm{OP})=1.00 \$ / \mathrm{L}$; (c) OST of Total Capital Cost for Jatropha Oil Price of $(\mathrm{OP})=1.25 \$ / \mathrm{L}$.

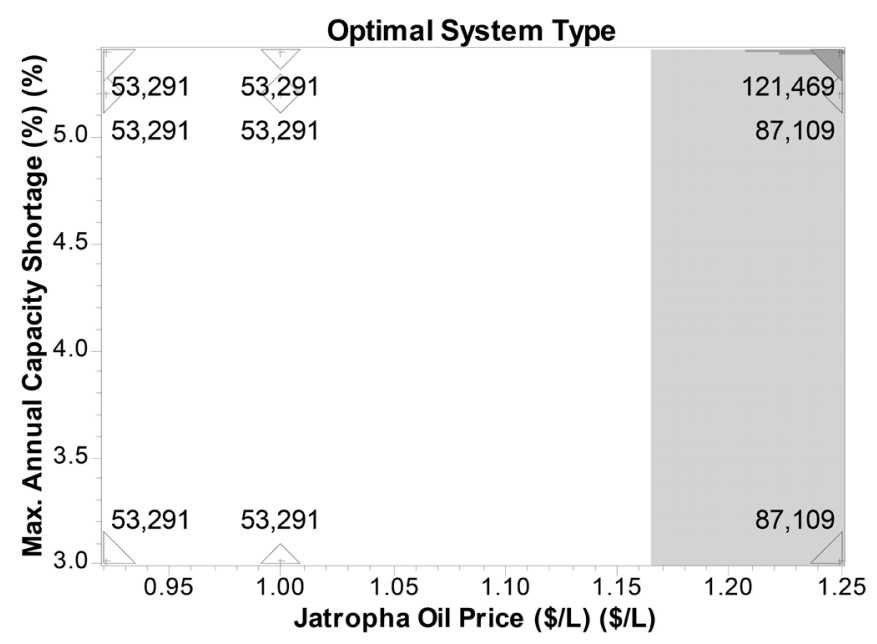

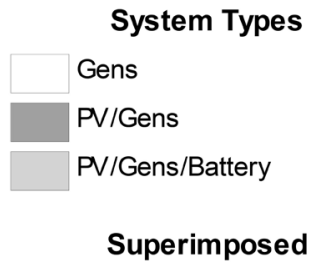

Total Eectrical Production (kWh/yr)

\section{Fixed}

Global Solar $=5.29 \mathrm{kWh} / \mathrm{m} ? \mathrm{~d}$

(a)

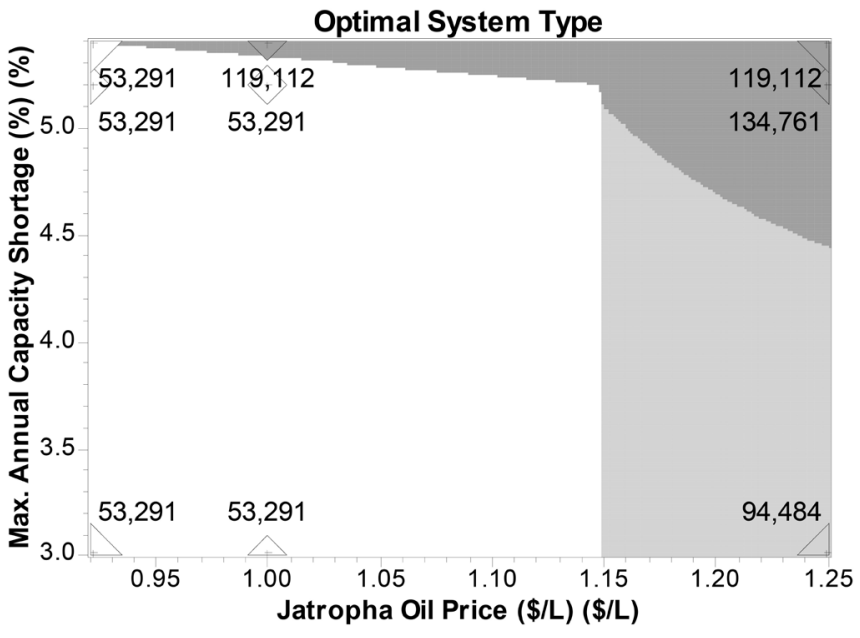

System Types

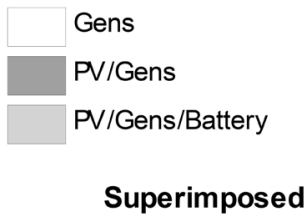

Total Eectrical Production (kWh/yr)

\section{Fixed}

Global Solar $=6.11 \mathrm{kWh} / \mathrm{m} ? \mathrm{~d}$

(b) 


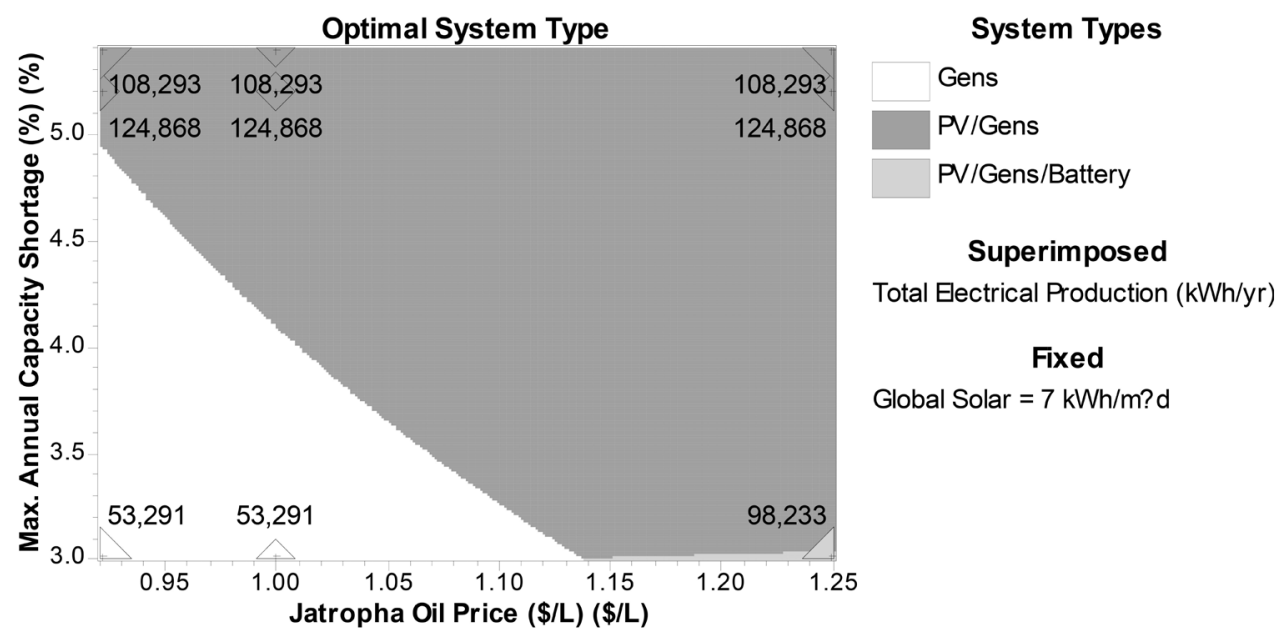

(c)

Figure 11. (a) OST of Total for electrical production global solar of $5.29 \mathrm{kWh} / \mathrm{m}^{2} / \mathrm{d}$; (b) OST of Total Electrical Production for global solar of $6.11 \mathrm{kWh} / \mathrm{m}^{2} / \mathrm{d}$; (c) OST of Total Electrical Production for global solar of $7.00 \mathrm{kWh} / \mathrm{m}^{2} / \mathrm{d}$.

(NPC) are respectively $348,873 \$$ and $398,557 \$$. The diesel system is the economically solution for Jatropha oil price less than $1.15 \$ / \mathrm{L}$. Indeed, above the slope line of global solar radiation from $\left(5.96 \mathrm{kWh} / \mathrm{m}^{2} / \mathrm{d}, 6.09 \mathrm{kWh} / \mathrm{m}^{2} / \mathrm{d}, 6.93\right.$ $\mathrm{kWh} / \mathrm{m}^{2} / \mathrm{d}$ to $6.98 \mathrm{kWh} / \mathrm{m}^{2} / \mathrm{d}$ ) $\mathrm{PV} /$ Gens system is economically acceptable. On the rest of the system, the hybrid PV/Gens/Battery is not recommended as we observe higher value of (NPC) when Jatropha oil price is more than $1.15 \$ / \mathrm{L}$ and global solar radiation is lower than $5.95 \mathrm{kWh} / \mathrm{m}^{2} / \mathrm{d}$. Considering Figure $11(\mathrm{c})$, this is shows that allowing 5.4\% of MACS, PV/Gens becomes suitable economically and especially for low price of Jatropha oil as shown in the plot. On the other hand, one observe that hybrid Gens/PV/Battery system disappears as seen from $1.16 \$ / \mathrm{L}$ to $1.19 \$ / \mathrm{L}$ of Jatropha oil price as shown in the plot because for his economic inefficiency.

Cost of Energy (COE) is shown in Figures 9(a)-(c). This is gives the price per kilowatt hour of energy. Capital cost and cost of energy (COE) for a fixed allowed maximum annual capacity shortage of $3 \%$ are respectively $15,000 \$$ and $0.698 \$ / \mathrm{kWh}$ for a Jatropha oil price less than $1.16 \$ / \mathrm{L}$ Figure $9(\mathrm{a})$. In this case, Gens system is suitable. In the other hand, for MACS $=5.2 \%$, Figure $9(\mathrm{~b})$, (COE) varies slightly $(0.696 \$ / \mathrm{kWh})$ which corresponds for PV/Gens hybrid system, the Capital cost increases and reached to $195,750 \$$. It is important to notice that PV/Gens/battery system is not recommended because of a higher cost of energy $0.796 \$ / \mathrm{kWh}$ and capital cost of $224,750 \$$.

When we allow a maximum capacity shortage of 5.4\% (Figure 9(c)), PV/Gens system is economically suitable for higher global solar radiation. In this condition, a photovoltaic based system out in to the plot for low global solar radiation and next (COE) becomes important.

Total Capital Cost (TCC) for fixed Jatropha oil price of $(0.92 \$ / \mathrm{L}, 1.00 \$ / \mathrm{L}$ and $1.25 \$ / \mathrm{L}$ ) is shown in the Figures 10 (a)-(c) respectively. For a fixed Jatropha oil 
price of $0.92 \$ / \mathrm{L}$ (Figure 10(a)), Gens system is economically suitable with $15,000 \$$ only for maximum annual capacity shortage less than $5.2 \%$. Above this value, the hybrid system PV/Gens appears in the curve as a solution just at the upper right corner of the curve with higher value. So integration of photovoltaic system is not recommended because of the value of total capital cost. Regarding in Figure 10(b) where Jatropha oil price is assumed to be $1.00 \$ / \mathrm{L}$ Gens stays also the feasible system irrespective of the global radiation value for maximum annual capacity shortage less than $4.09 \%$. Indeed, comparing the case where Jatropha oil price were assumed to be $0.92 \$ / \mathrm{L}$, it is found that its increase shows the photovoltaic hybrid system, PV/Gens, as a solution in order to balance the overall price of the system.

On the other hand, the tendency is reversed in the case where Jatropha oil price is exorbitant $1.25 \$ / \mathrm{L}$ (Figure $10(\mathrm{c})$ ) and $\mathrm{PV} / \mathrm{Gens} /$ Battery might be suitable economically with 159,350 of Total Capital Cost. It is recommended to use PV/Gens/Battery hybrid system when Jatropha oil price is elevated. This situation can be explained by a remoteness of the site (Village) of the urban area or when an unforeseen price hike of Jatropha oil reigns. Cost of energy is $0.781 \$ / \mathrm{kWh}$ for $\mathrm{PV} / \mathrm{Gens} /$ Battery hybrid system while for $\mathrm{PV} / \mathrm{Gens}$ system its decreases for $0.681 \$ / \mathrm{kWh}$ with high maximum annual capacity shortage.

Global solar radiation is presented as sensitivity factor which can influence the choice of dimensioning of a hybrid system. Figures 11(a)-(c) explains this situation where different value of global solar radiation were taken on account in this study for total electricity production. Indeed, regarding Figure 11(a) it is observed that for Jatropha oil price less than $1.16 \$ / \mathrm{L}$ Gens is economically feasible for a total electricity production of $53,291 \mathrm{kWh} / \mathrm{yr}$ when global solar radiation is $5.29 \mathrm{kWh} / \mathrm{m}^{2} / \mathrm{d}$. above this considered value of Jatropha oil $\mathrm{PV} / \mathrm{Gens} /$ Battery might be suitable with $87,109 \mathrm{kWh} / \mathrm{yr}$. This value is considered very high compared to the last. PV/Gens are weakly observed in the upper of the plot with high value of maximum annual capacity shortage. This combination can be taken in account when we want to produce electricity more for the future $(121,469 \mathrm{kWh} / \mathrm{yr})$ while the annual average need for energy consumption in the remote area is estimated about to $52,560 \mathrm{kWh} / \mathrm{yr}$. For a global solar radiation fixed at $6.11 \mathrm{kWh} / \mathrm{m}^{2} / \mathrm{d}$, Figure $11(\mathrm{~b})$, photovoltaic system becomes more and more important in the hybrid system. It is important to notice that Gens stays the favourable system for Jatropha oil price less than $1.15 \$ / \mathrm{L}$ with a total net present cost of 364,928\$ while for integration of the PV system (PV/Gens and $\mathrm{PV} / \mathrm{Gens} /$ Battery) the electricity production is elevated which also requires an important financial cost. In this case net present cost is estimated at $398,178 \$$ for $\mathrm{PV} / \mathrm{Gens}$ and 400,314 for PV/Gens/Battery hybrid system. So integration PV system elevates electrical production. Figure 11(c) shows that when global solar radiation is important $7.00 \mathrm{kWh} / \mathrm{m}^{2} / \mathrm{d}$, the hybrid system $\mathrm{PV} /$ Gens produces more electricity.

For Jatropha oil price superior to $1.14 \$ / \mathrm{L}$, Figure $11(\mathrm{c})$ shows that PV/Gens/Battery hybrid system is reported with $98,233 \mathrm{kWh} / \mathrm{yr}$. On the other 
hand, Total Net Present, Total capital cost and cost of energy are respectively of $324,733 \$ ; 116,750 \$$ and 0.629 for PV/Gens hybrid system. Gens system is suitable only for low Jatropha price while integration of photovoltaic system drops Net present cost and PV/Gens system become probably the only economically feasible system for community (village).

Indeed, by introducing a certain annual shortage of capacity to the HOMER simulations, the range where $\mathrm{PV} /$ diesel/battery systems become more profitable than the PV/battery system decreases for higher sunshine. This phenomenon is gaining ground more and more that the global sunlight is increasing; in this case the system PV/People becomes economical feasible. Allowing part of the load to be dedicated throughout the year means that the photovoltaic network is more favorable to offset the reported shortage.

\subsection{Optimization Results}

Optimization results are characterized by a particular set of sensitivity parameters which give the best choice of the hybrid system. The best optimization results is selected by a PV/Gens system with an oil Jatropha price of $1.250 \$ / \mathrm{L}$ for a global solar irradiation of $8.5 \mathrm{kWh} / \mathrm{m}^{2} / \mathrm{d}$. The power of photovoltaic panels is 80 $\mathrm{kW}$ for a power Gens of $120 \mathrm{~kW}$. String size of 24 batteries was used for 4 strings in parallel, so a total of 120 batteries for this system with a bus voltage of $48 \mathrm{~V}$ have been detected. Converter and rectifier powers are $15 \mathrm{~kW}$ for each one. Initial Capital is $159,350 \$$ and operating costs is set at 25,366 $\$$ yr. The Total Net Capital Cost is 408,401 , and Jatropha oil consumption is $11,380 \mathrm{~L} / \mathrm{yr}$ for operating of $8745 \mathrm{hrs} / \mathrm{yr}$ for Gens. Livelized cost is $0.781 \$ / \mathrm{kWh}$ and cash flow shows that, battery replacement must be done after 12 years. Cost summary shows that, Total cost of PV, diesel Gens, battery, converter, others and total system are $127,389 \$ 207,510 \$ ; 33,382 \$ ; 15,575 \$ 24,545 \$$ and $408,401 \$$ respectively. Monthly average electric production shows that PV array must produce 56,810 $\mathrm{kWh} / \mathrm{yr}$ for $98 \%$ of operating and $1534 \mathrm{kWh} / \mathrm{yr}$ for the Diesel Generator for $2 \%$ of operating. Therefore $75,869 \mathrm{kWh} / \mathrm{yr}$ was used at $100 \%$ of operation. The monthly distribution of the electricity produced in $\mathrm{kW}$ by the system show that in April to October, PV system works almost $100 \%$ while the other months PV system works in $94 \%$. The peak $(8.7 \mathrm{~kW})$ load is met for May and August where demand is greater. Green house gases emissions are summarized in Table 4 for more details about global gases emissions for hybrid system.

\section{Conclusions}

In the present study, design of hybrid power system for a power supply in rural areas in Comoros was conducted using HOMER software tool. The hybrid system composed by PV/Gens has been studied with sensitivity parameters for Jatropha oil price and global solar irradiation in order to optimize the system. Taking into account of the changes of the sensitivity parameters, hybrid system shows that $96 \%$ of electricity is produced from Photovoltaic panels. On the other 
Table 4. Green house gases for Jatropha and hybrid systems.

\begin{tabular}{cc}
\hline Pollution & Emission $(\mathrm{kg} / \mathrm{yr})$ \\
\hline Carbon dioxide & -5.2 \\
Carbone monoxide & 3.31 \\
Unburned hydrocarbons & 1.2 \\
Particulate matter & 0 \\
Sulfur dioxide & 0 \\
Nitrogen oxides & 5.63 \\
Total & 4.94 \\
\hline
\end{tabular}

hand, during one year of hybrid system operation, the PV only works on seven months (April to October), therefore operation at $100 \%$. Indeed, the advantage of using a hybrid system is that, not only fuel consumption reduction, but also reduction of greenhouse gas emissions in order to fight against climate change and we notice that in the present work, this goal is achieved. On the other hand, the reduction of electricity cost consumption is viable for rural people with a cost of $0.681 \$ / \mathrm{kWh}$. It is important to notice that, a PV/Gens system is the most suitable solution for this application. Cost of energy for this study is around $0.681 \$ / \mathrm{kWh}$ for MACS $=5.2 \%$ instead of $0.781 \$ / \mathrm{kWh}$. For a low Jatropha price $\mathrm{PV} / \mathrm{Gens}$ hybrid system is economically feasible while for high value of Jatropha oil price, PV/Gens/Battery is recommended. In fact, the economies of scale might bring down the cost of energy at the future towards the present cost electricity price of fuel gasoil $(0.244 \$ / \mathrm{kWh})$ in the national society for electricity production, MAMWE, in Comoros. The system shows that the use of Jatropa oil as a fuel has a favorable advantage over the protection of the environment. The latter has no significant effect on the protection of the environment from the release of greenhouse gases, as opposed to the utility of other fuels such as diesel whose effect would be significant because of the presence of the sulfur dioxide gas. Indeed, among the advantages of the hybrid system in rural area it can be noted that:

1) Creation of infrastructures for the establishment and the extension of the superfluous electricity grid.

2) High reliability power system and decline in market prices PV savings on.

Investment costs and multiple technical configurations such as economy on operating costs.

3) Limited maintenance, extended warranty and ecological silent system.

\section{Acknowledgements}

The authors would like to acknowledge the Culture Action Cooperation Service of the Embassy of France and Campus France in Union of Comoros for their financial support. 


\section{Conflicts of Interest}

The authors declare no conflicts of interest regarding the publication of this paper.

\section{References}

[1] Traca, A., et al. (1983) Source Reliability in a Combined Wind-Solar-Hydro System. IEEE Transactions on Power Apparatus and Systems, 102, 1515-1520. https://doi.org/10.1109/TPAS.1983.317879

[2] Elhadidy, M.A. and Shaahid, S.M. (2000) Parametric Study of Hybrid (Wind + Solar + Diesel) Power Generating Systems. Renewable Energy, 21, 129-139. https://doi.org/10.1016/S0960-1481(00)00040-9

[3] Shaahid, S.M. and Elhadidy, M.A. (2005) Optimal Sizing of Battery Storage for Stand-Alone Hybrid (Photovoltaic + Diesel) Power Systems. International Journal of Sustainable Energy, 24, 155-166. https://doi.org/10.1080/14786450500292188

[4] Shaahid, S.M. and Elhadidy, M.A. (2008) Economic Analysis of Hybrid Photovoltaic-Diesel-Battery Power Systems for residential Loads in Hot Regions-A Step to Clean Future. Renewable and Sustainable Energy Reviews, 12, 488-503. https://doi.org/10.1016/j.rser.2006.07.013

[5] Nayar, C.V., Phillips, S.J., James, W.L., Pryor, T.L. and Remmer, D. (1993) Novel Wind/Diesel/Battery Hybrid Energy System. Solar Energy, 51, 65-78. https://doi.org/10.1016/0038-092X(93)90043-N

[6] Luiz, C.G.V. and Silvio, C.A.A. (1998) Economic Analysis of Diesel/Photovoltaic Hybrid System for Decentralized Power Generation in Norther Brazil. Energy, 23, 317-323. https://doi.org/10.1016/S0360-5442(97)00094-7

[7] Elhadidy, M.A. and Shaahid, S.M. (1999) Optimal Sizing of Battery Storage for Hybrid (Wind + Diesel). Power Systems, 18, 77-86.

[8] Elhadidy, M.A. and Shaahid, S.M. (2004) Promoting Applications of Hybrid (Wind + Photovoltaic + Diesel + Battery) Power Systems in Hot Regions. Renew Energy, 29, 517-528. https://doi.org/10.1016/j.renene.2003.08.001

[9] Notton, G., Muselli, M. and Louche, A. (1996) Autonomous Hybrid Photovoltaic Power Plant Using a Back-Up Generator: A Case Study in a Mediterranean Island. Renew Energy, 7, 371-391. https://doi.org/10.1016/0960-1481(96)00016-X

[10] El-Hefnawi, S.H. (1998) Photovoltaic Diesel-Generator Hybrid Power System Sizing. Renew Energy, 13, 33-40. https://doi.org/10.1016/S0960-1481(97)00074-8

[11] Valente, L.C.G. and Almeida, S.C.A.D. (1998) Economic Analysis of a Diesel/Photovoltaic Hybrid System for Decentralized Power Generation in Northern Brazil. Energy, 23, 317-323. https://doi.org/10.1016/S0360-5442(97)00094-7

[12] Wichert, B. (1997) PV-Diesel Hybrid Energy Systems for Remote Area Power Generation-A Review of Current Practices and Future Developments. Renewable and Sustainable Energy Reviews, 1, 209-228. https://doi.org/10.1016/S1364-0321(97)00006-3

[13] Al-Badi, A.H. and Bourdoucen, H. (2009) Economic Analysis of Hybrid Power System for Rural Electrification in Oman. 2nd International Conference on Adaptive Science \& Technology, Accra, 14-16 Jane 2009, 284-289. https://doi.org/10.1109/ICASTECH.2009.5409712

[14] Elhadidy, M.A. (2002) Performance Evaluation of Hybrid (Wind + Solar + Diesel) Power Systems. Renewable Energy, 26, 401-413. 
https://doi.org/10.1016/S0960-1481(01)00139-2

[15] Kusakana, K. and Vermaak, H.J. (2014) Hybrid Diesel Generator/Renewable Energy System Performance Modelling. Renewable Energy, 67, 97-102. https://doi.org/10.1016/j.renene.2013.11.025

[16] Bernal-Agustin, J.L. and Dufo-Lopez, A. (2009) Simulation and Optimization of Stand-Alone Hybrid Renewable Energy Systems. Renewable and Sustainable Energy Reviews, 13, 2111-2118. https://doi.org/10.1016/j.rser.2009.01.010

[17] Ali Saleh, A., Mohammad, F.N.T. and Mohd, R.A. (2018) Feasibility Analysis of PV/Wind/Battery Hybrid Power Generator: A Case Study. International Journal of Renewable Energy Research, 8, 661-671.

[18] Khan, M.J. and Iqbal, M.T. (2005) Pre-Feasibility Study of Stand-Alone Hybrid Energy Systems for Applications in Newfoundland. Renewable Energy, 30, 835-854. https://doi.org/10.1016/j.renene.2004.09.001

[19] Cadre réglementaire sur les énergies renouvelables aux Comores (2016) Etat de lieu et possibilité d'amélioration.

[20] Duffie, J.A. and Beckman, W.A. (1991) Solar Engineering of Thermal Processes. 2nd Edition, Wiley, New York.

[21] Kassim, M.A. and El Ganoui, M. (2017) Feasibility Study for the Production of Electricity Using a Hybrid PV-Winde-Generator System in a Remote Area in Comoros. International Journal of Research and Reviews in Applied Sciences, 33, 23-36.

[22] Chiemeka, I.U. and Chineke, T.C. (2009) Evaluating the Global Solar Energy Potential at Uturu, Nigeria. International Journal of Physical Sciences, 3, 115-119.

[23] Elhadidy, M.A. and Shaahid, S.M. (1999) Optimal Sizing of Battery Storage for Hybrid (Wind + Diesel) Power Systems. International Journal of Renewable Energy, 18, 77-86. https://doi.org/10.1016/S0960-1481(98)00796-4

[24] Rehmana, S., El-Aminb, I.H., Ahmada, F., Shaahida, S.M., Al-Shehrib, A.M., Bakhashwainb, J.M, and Shah, A. (2017) Feasibility Study of Hybrid Retrofits to an Isolated Off-Grid Diesel Power Plant, Renewable and Sustainable, Energy Reviewers, $11,635-653$

[25] Elhadidy, M.A. and Shaahid, S.M. (1994) Effect of Kuwait's Oil-Firere Smoke Cloud on Global Horizontal Irradiance at Dhahran, Saudi Arabia. Solar Energy, 52, 439-446. https://doi.org/10.1016/0038-092X(94)90121-H 